Araştırma Makalesi / Research Article

Geliş tarihi / Received: 16.09.2020

Kabul tarihi / Accepted: 30.03.2021

Atıf İçin: Çetinkaya T, Altay F, Ceylan Z, 2021. Depolama Süresince Balıketi Kalitesinde Meydana Gelen Değişimlerin Hızlı ve Yenilikçi Metotlarla Belirlenmesi. Iğdır Üniversitesi Fen Bilimleri Enstitüsü Dergisi, 11(3): 2030-2040.

To Cite: Çetinkaya T, Altay F, Ceylan Z, 2021. Determination of Fish Meat Quality Changes by Fast and Novel Methods During Storage Period. Journal of the Institute of Science and Technology, 11(3): 2030-2040.

\title{
Depolama Süresince Balıketi Kalitesinde Meydana Gelen Değişimlerin Hızlı ve Yenilikçi Metotlarla Belirlenmesi
}

\section{Turgay ÇETINKAYA ${ }^{1,2}$, Filiz ALTAY ${ }^{3}$, Zafer CEYLAN $^{4 *}$}

ÖZET: Farklı üç balık türünün (yerli somon: YS, çipura: Ç, levrek: L) et kısımlarında yapılan analizler ile literatürde fazla yer almayan ve nadir çalışılan bazı fiziksel parametreler yardımıyla balıketlerinin kalite değişimleri 0. 2. ve 4. günlerde incelenmiştir. $\mathrm{Bu}$ bağlamda, örneklere ve depolamaya bağlı değişmekle birlikte, elektriksel iletkenlik değeri $\left(\mathrm{mS}^{-1}\right)$ \%9.52 ile \%104 arasında artış göstermiştir. Yüzey gerilimi değeri ise depolama süresinin artışına bağlı olarak azalmıştır. Ç örneklerinde bu değer $42.56 \mathrm{mN} \mathrm{m}{ }^{-1}$ den hızlıca azalma göstererek depolamanın ikinci gününde $16.20 \mathrm{mN} \mathrm{m}^{-1}$, e kadar düşmüştür $(p<0.05)$. Dielektrik kayıp faktörü $\left(\varepsilon^{\prime \prime}\right)$ ise tüm örneklerde, analiz periyoduna bağlı olarak artış göstermiştir. Duyusal değerlendirme sonuçlarına göre Ç ve L örnekleri ikinci gün itibari ile tüketilemez olarak kabul edilirken bu örneklerin dielektrik kayıp faktörünün sırası ile 419.72'den 491.07'ye ve 408.21'den 430.7'ye arttığı gözlenmiştir. Öte yandan partikül boyutu (PB) ve polidispersite indeks (PDI) değerleri ile anlamlı bir sonuç elde edilememiștir. Yaygı́n olarak kullanılan $\mathrm{pH}$ analizi sonuçları ise yüzey gerilimi ve elektriksel iletkenlikteki değişimleri doğrular nitelikte bulunmuş olup, depolama süresinin artışına bağlı olarak pH değerleri artış göstermiştir. Bu çalışmanın sonuçları, kısa sürede bozulabilen ürünlerin farklı ve hızlı yenilikçi analiz yöntemleri ile kalitelerinin başarılı bir şekilde ortaya konulabileceğini göstermiştir. Ayrıca diğer çalışmalar ve gıda işleme sektörü için rehber değeri taşıyan bir çalışma ortaya konulmuştur.

Anahtar Kelimeler: Balıketi, elektriksel iletkenlik, yüzey gerilimi, dielektrik kayıp faktörü, partikül boyutu, kalite

\section{Determination of Fish Meat Quality Changes by Fast and Novel Methods During Storage Period}

ABSTRACT: Quality changes of three different fish species (local salmon: YS, bream: Ç, sea bass: L) were examined at 0., 2., and 4. days with the help of some physical parameters that were rarely studied and were not much included in the literature. In this context, the electrical conductivity value $\left(\mathrm{mS} \mathrm{cm}^{-1}\right)$ of the samples increased between $9.52 \%$ and $104 \%$ depending on the samples and storage. Surface tension values decreased by increasing the storage time. In Ç samples, this value declined rapidly from $42.56 \mathrm{mN} \mathrm{m}^{-1}$ to $16.20 \mathrm{mN} \mathrm{m}^{-1}$ on the second day of storage $(\mathrm{p}<0.05)$. The dielectric loss factor $\left(\varepsilon^{\prime \prime}\right)$ increased in all samples depending on the analysis period. According to the sensory evaluation results, while the Ç and $\mathrm{L}$ samples are considered as non-consumable as of the second day, it has been observed that the dielectric loss factor of these samples increased from 419.72 to 491.07 and from 408.21 to 430.7, respectively. On the other hand, no significant results were obtained with particle size (PB) and polydispersity index (PDI) values. Commonly used pH analysis results have been found to confirm these changes as $\mathrm{pH}$ values increased by increasing storage times. In this context, the results of this study have shown that the quality of the rapidly perishable products can be successfully demonstrated with different and fast innovative analysis methods. Moreover, a novel study has been presented that is also a guide for other studies and the food processing sector.

Keywords: Fish meat, electrical conductivity, surface tension, dielectric loss factor, particle size, quality

\footnotetext{
${ }^{1}$ Turgay ÇETINKKAYA (Orcid ID: 0000-0003-2962-1241), İstanbul Teknik Üniversitesi, Lisansüstü Eğitim Enstitüsü, Gıda Mühendisliği Bölümü, İstanbul, Türkiye

${ }^{2}$ Yalova Üniversitesi, Armutlu Meslek Yüksekokulu, Gıda İşleme Bölümü, Yalova, Türkiye

${ }^{3}$ Filiz ALTAY (Orcid ID: 0000-0002-5484-866X), İstanbul Teknik Üniversitesi, Kimya-Metalurji Fakültesi, Gıda

Mühendisliği Bölümü, İstanbul, Türkiye

${ }^{4}$ Zafer CEYLAN (Orcid ID: 0000-0002-6527-4382), Van Yüzüncü Y1l Üniversitesi, Turizm Fakültesi, Gastronomi ve Mutfak Sanatları Bölümü, Van, Türkiye

*Sorumlu Yazar/Corresponding Author: Zafer CEYLAN, e-mail: zaferceylan@yyu.edu.tr

Bu çalışma danışmanlığını Prof. Dr. Filiz Altay (1. Danışman) ve Doç. Dr. Zafer Ceylan’ın (Eş danışman) yaptığı, Turgay Çetinkaya'nın doktora tezinin bir parçası olarak tasarlanmıştır.
} 


\section{GíRiş}

Gıda materyalleri ve bunların ürünlerinin kalitesi, dayanıklılığı hem üretici hem de tüketici için önemlidir. Diğer önemli noktalardan birisi de üretilen ürünün kalitesinin ve kalite değişimlerinin de hızlı bir şekilde ortaya konulmasıdır. Bu amaçla özellikle mikrobiyolojik analiz yöntemleri (toplam mezofilik aerobik bakteri: TMAB) yaygın olarak kullanılmaktadır. Bunun yanı sıra özellikle bilimsel alanda duyusal analizler de önemli yer tutmaktadır. Hatta çoğu durumda ve araştırmalarda mikrobiyal gelişimde meydana gelen değişimler ve duyusal karakterde (renk, koku, doku vs.) meydana gelen değişimlerle de ilişkilendirilebilmektedir (Bendini ve ark., 2007; Özogul ve ark., 2016; Ozogul ve ark., 2017). Özellikle balıketi ve ürünlerinde kalitenin belirlenmesinde yukarıda bahsedilen analizlerin yanı sıra, kimyasal (toplam uçuçu bazik azot: TVBN) ve fizikokimyasal analizler de oldukça yaygın olarak kullanılmaktadır (Ceylan ve ark., 2017). Tekstür ve renk gibi bazı fiziksel analizler de balıketi kalitesinin ortaya konulmasında kullanılmaktadır (Ceylan ve Meral, 2018). Dahası, çoğu balıketi veya türüne bağlı olarak sınır değerler de hem kimyasal hem de mikrobiyal analizler için tanımlanmıştır. Örneğin, TMAB için 6$7 \log \mathrm{KOB} \mathrm{g}^{-1}$ ya da TVBN için $30 \mathrm{mg} \mathrm{g}^{-2}$ gibi değerler mevcut olup, duyusal analizde ise farklı yöntemler var olmakla beraber 10 veya 9 üzerinden değerlendirmelerde sırası ile 5 ve 4 puan pek çok çalışmada sınır değer olarak kabul edilmektedir (ICMSF, 1986; Fan ve ark., 2009; Chotimarkorn, 2014; Ceylan ve ark., 2017; Ceylan ve ark., 2018).

Balıketi kasaplık hayvan etlerine kıyasla özellikle bağ dokusunun zayıf olması, su oranın yüksek olması, iç organlarının daha yumuşak olması gibi nedenlerden dolayı daha hızla bozulabilmektedir (Külcü, 2017). Bu bozulmaları geciktirmek için, örneklerin özellikle hasat ya da avlama işleminden hemen sonra tekne üzerinde buzlanması gerekmektedir (Nair, 2002). Bu işlemden hemen sonra soğuk muhafazaya alınmalıdır. Ancak bundan sonra ürünler amacına uygun olarak işlenmek üzere fabrikalara da sevk edilebilir. Bu noktada taze olarak satışa sunulan ürünler soğuk muhafazada, daha uzun vadeli depolanacak ürünler ise 1şınlama teknolojisi, sous vide, modifiye atmosferde paketleme gibi işlemlere tabi tutulabilirler (Gerdes ve Santos Valdez, 1991; Díaz ve ark., 2011; Ceylan ve Özoğul, 2019). Böylece ürünlerin raf ömrü genelde 4 gün ile muhafaza ve işleme yöntemine bağlı olarak 6 ay hatta bir y1la kadar uzatılabilmektedir.

Muhafaza süresince meydana gelen değişimleri ve raf ömrünü belirlemek için yukarıda belirtilen analizler hali hazırda yapılmaktadır. Ancak bu yöntemler hem zaman hem de maliyet açısından etkin değildir. Özellikle son yıllarda balıketi muhafazasında maliyet fayda ilişkisi yüksek olan (nanoteknolojik) yöntemlere olan ilgi artarken (Ceylan, 2019), kalitede meydana gelen değişimleri incelemek içinde farklı yöntemler yaygın olarak uygulanmaktadır (Çetinkaya ve Ceylan, 2020). Bu amaçla kalitedeki değişimlere bağlı olarak özellikle elektriksel iletkenlik değerinde meydana gelen değişimler, yüzey gerilimindeki farklılıklar, dielektrik kayıp faktörü, zeta potansiyeli, PB ve PDI değerleri gıda sektöründe kullanılmaya başlamıştır. Güzel ve Bahçeci (2020)'ye göre; elektriksel iletkenlik değeri ürünün protein konsantrasyonu ile de ilişkili olabilmektedir. Yüzey gerilimi birim uzunluğa uygulanan kuvvet sonucu materyal yüzeyinin $1 \mathrm{~cm}^{2}$ artırılması prensibine dayanmaktadır. Yüzey gerilimi yüzey serbest enerjisi olarak da tanımlanmaktadır (Tyson ve Miller 1977). Bu noktada, Aydar ve Bağdatlığlu (2014) yağlar ile yüzey gerilimi arasında bir ilişki olduğunu belirtmişlerdir. Gıdanın bileşenleri bu değerlerin belirlenmesinde rol oynayabilmektedir. Ayrıca, gıdanın dielektrik özellikleri ile nem içeriği arasında bir ilişki olabileceği belirtilmiştir (Komarov ve ark., 2005). Gıda sistemlerindeki elektriksel etkileşimler gıdanın raf ömrünün belirlenmesinden, rengine ve reolojik özelliklerine kadar pek çok faktörü etkileyebilmektedir (Cano-Sarmiento ve ark., 2018). Bu bakımdan PB veya zeta potansiyelinin değerlendirilmesi de yenilikçi bir yaklaşım olarak ortaya çıkmaktadır. 
Protein gibi monodispers bir polimer için PDI değeri 1 olarak tanımlanmaktadır. Bu yüzden proteince zengin bir materyaldeki depolama boyunca elde edilen çözeltinin PDI değeri de incelenmelidir.

$\mathrm{Bu}$ çalışmanın ana hedefi, depolama süresi boyunca, ülkemizde yaygın olarak tüketilen üç farklı balık türlerindeki (yerli somon, çipura ve levrek) kalite değişimlerini farklı analiz yöntemleri ile incelemektir. Örneklerin elektriksel iletkenlik, yüzey gerilimi, dielektrik kayıp faktörü, PB, ve PDI değerlerindeki değişimleri ortaya konularak, balıketi örneklerindeki kalite değişimlerini tespit etmek için yenilikçi ve adapte edilmiş analiz sonuçlarının bu çalışma ile sunulması amaçlanmıştır.

\section{MATERYAL VE METOT}

Yerli somon (YS), çipura (Ç) ve levrek (L) örnekleri uluslararası bir firmadan temin edilmiştir. Örnekler, soğuk muhafaza altında İstanbul Teknik Üniversitesi, Gıda Mühendisliği bölümüne getirilip derhal $10 \pm 2{ }^{\circ} \mathrm{C}$ 'de muhafazaya alınmıştır.

PB ve PDI değerleri Zetasizer Nano ZS (Malvern Instruments, Worcestershire, İngiltere) kullanılarak gerçekleştirilmiştir. Solüsyon küvete konulmuş olup, $4.0 \mathrm{mV}$ He-Ne lazer (633 nm) ile 25 ${ }^{\circ} C^{\prime}$ deki ortam sıcaklığında ölçümler gerçekleştirilmiştir. pH analizi için HANNA HI 221 (Hanna Instruments Inc., Woonsocket-RI-USA, Romania) pH metre cihazı kullanılmıştır. Örneklerden 1'er g alınmış üzerine $10 \mathrm{~mL}$ saf su ilave edilerek Silent Crucher S homojenizatörü (Heidolph Instruments, D91126, Schwabach, Germany) ile dakikada 75000 devirde yaklaşık 50 saniye homojenize edilmiş, sonrasında probun solüsyona daldırılması ile ölçüm gerçekleştirilmiştir. Dielektrik kayıp faktörü analizi için, $1 \mathrm{~g}$ örnek $10 \mathrm{~mL}$ saf su ile homojenize edilmiştir. Ardından, prop (Agilent 5070E) hazırlanan solüsyona daldırılarak Network Anaylzer (Agilent Technologies E5061B ENA Series USA) cihazıyla $100 \mathrm{kHz}-3 \mathrm{GHz}$ frekans şartları altında sonuçlar elde edilmiştir. $30 \mathrm{mHz}$ frekansındaki değerler incelenmiştir. Elektriksel iletkenlik analizleri için $1 \mathrm{~g}$ örnek $100 \mathrm{~mL}$ saf su ile homojen hale getirilmiş olup, WTW LF95 (Wissenschaftlich-Technische Werkstätten GmbH \& Co. Weilheim, Germany) cihazı kullanılarak örneklere ait değerler miliSiemens santimetre ${ }^{-1}\left(\mathrm{mS} \mathrm{cm}^{-1}\right)$ biriminde ölçülmüştür. Yüzey gerilimi analizi için örnekler 1:100 (w:v) olarak ayrı ayrı seyreltilmiş, tensiyometre (Dataphysics DCAT $11 \mathrm{E}$, Germany) ve PT 11 Wilhelmy plate 20003232 probu (Platinum-Iridium, uzunluk: $10 \mathrm{~mm}$, genişlik: $19.9 \mathrm{~mm}$, kalınlık: $0.2 \mathrm{~mm})$ kullanılarak $25{ }^{\circ} \mathrm{C}^{\text {' de miliNewton metre }}{ }^{-1}\left(\mathrm{mN} \mathrm{m}^{-1}\right)$ biriminde ölçümler gerçekleştirilmiştir. Duyusal analizler için ise, 9 puan en yüksek puan olarak tanımlanmış olup, 4 puan ürünün panelistler tarafından tüketilemez olarak kabul ettikleri sınır değer olarak tanımlanmıştır (Ceylan ve ark., 2018). Çalışma sonucunda elde edilen veriler JMP (SAS Campus Drive, USA Versiyon 14) istatistik yazılım programında One-Way tek yollu ANOVA analizine tabi tutularak, örneklerin depolama süresi boyunca oluşan istatistiksel farklılıklar $\mathrm{p}<0.05$ önem derecesinde Duncan çoklu karşılaştırma testi ile ortaya konulmuştur.

\section{BULGULAR VE TARTIŞMA}

\section{pH}

pH değerlerindeki değişimler Çizelge 1'de sunulmuştur. Glikojenin laktik aside dönüşümü ile beraber $\mathrm{pH}$ değeri kısa süreliğine avlamadan sonra düşüş gösterebilmektedir. Ancak depolama süresinin artışına bağlı olarak balıketinin $\mathrm{pH}$ değerinde artış gözlenebilmekte ve bu değer tazelikle ilişkilendirilmektedir (Abbas ve ark., 2008; Ceylan ve ark., 2018). Sunulan çalışmada, YS, Ç ve L gruplarının başlangıç pH değerleri sırası ile, 6.38, 6.27 ve 6.36 olarak tespit edilmiştir. Depolamanın 2. gününde artış oranları en yüksek L örneklerinde (\%5.34), en düşük artış ise YS (\%1.25) örneklerinde tespit edilmiştir. Son analiz gününde ise, $\mathrm{pH}$ değeri Ç örneklerinde 6.81 olarak tespit edilirken, L ve YS örnekleri ise diğer gruplara kıyasla daha düşük değerlere sahip olduğu tespit edilmiştir. Kayim ve Can 
(2010) yaptıkları çalışmada, son analiz gününde balıketinin pH değerinin 6.8 olarak tespit etmişlerdir. pH değerindeki bu artışı bozulan balıketindeki bakteriyel metabolitlerin artışı ile ilişkilendirmişlerdir. Çalışmamızda oranları farklı olsa da YS, Ç ve L örneklerinin pH değerlerinde zamana bağlı olarak artış olduğu tespit edilmiştir.

Çizelge 1. Depolamaya bağlı olarak örneklerdeki pH değişimleri

\begin{tabular}{lccc}
\hline & 0. Gün & 2. Gün & 4. Gün \\
\hline Yerli Somon & $6.38^{\mathrm{c}} \pm 0.03$ & $6.46^{\mathrm{b}} \pm 0.03$ & $6.51^{\mathrm{a}} \pm 0.01$ \\
Çipura & $6.27^{\mathrm{c}} \pm 0.02$ & $6.51^{\mathrm{b}} \pm 0.02$ & $6.81^{\mathrm{a}} \pm 0.02$ \\
Levrek & $6.36^{\mathrm{c}} \pm 0.01$ & $6.70^{\mathrm{b}} \pm 0.03$ & $6.76^{\mathrm{a}} \pm 0.01$ \\
\hline
\end{tabular}

$\mathrm{a}, \mathrm{b}, \mathrm{c}$ harfleri analiz günleri arasındaki istatistiksel farklılığı ifade etmektedir $(\mathrm{p}<0.05)$

\section{Elektriksel İletkenlik}

Elektriksel iletkenlik değerleri Şekil 1'de gösterilmiştir. Örneklerin başlangıç iletkenlik değerleri

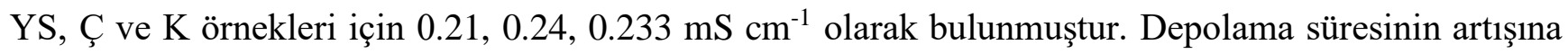
paralel olarak, 2. günde YS örneklerinin iletkenlik değeri 0.23'e çıkmıştır (artış: \%9.52). Benzer olarak Ç (artış: \% 16.66: p<0.05) ve L (artış: \%20.00: p <0.05) örneklerinin değerlerinde de artış tespit edilmiştir. Ç ve K örnekleri duyusal olarak depolamanın 2. gününde tüketilemez olarak düşünüldüğünde, Ç ve L'ye ait bu değerler aslında bozuk olarak tespit edilmiş ürünün ulaşabileceği değerler olarak kabul edilebilir. Ancak YS örneklerinde depolamanın 4. gününde, depolamanın 2. gününe kıyasla \%48.57 artış görülmüştür $(p<0.05)$. Gıdaların elektriği ilettiği bilinmektedir. Metallerin aksine, gıdalardaki yük taşıyıcılar elektronlar yerine iyonlardır. Normal uygulamalarda, iyon kütlesi elektrik alanı boyunca hareket ederken, iyonlar yükleri taşır. İyonların konsantrasyonu ve hareketliliği elektriksel iletkenliği belirler (Zhang, 2007). Ürünlerin elektriksel iletkenlik değerleri arasındaki bu farklılıkların birkaç sebebi olabilmektedir. Bunlardan ilki ürünlerin başlangıç kaliteleri arasındaki farklılıklar diğeri ise ürünleri sahip olduğu besin bileşimi olarak değerlendirilebilir (Jha ve ark., 2011; Kaya ve İçier, 2019). Bilindiği üzere bozulma ile yağların yanı sıra beraber proteinlerin yapısında da değişimler/yıkımlanmalar meydana gelebilmektedir. İletkenlik değeri ile protein içeriği ya da yüzdesi arasında bir ilişki olabileceği daha önceki çalışmalarda ortaya konulmuştur. Ayrıca, Souza ve ark. (2010) yaptıkları çalışma ile süre artışına bağlı olarak et örneklerindeki iletkenlik değerinin arttığını tespit etmişlerdir. Bunun nedeni ise hücre zarlarının zamanla zarar görmesi ve iyon salınımının artması olarak tarif edilmiştir (Pliquett ve ark., 2003). Bu sonuçlar göstermektedir ki, kalitenin tespit edilmesinde, elektriksel iletkenlik değeri yaygın olarak bilimsel çalışmalar ve gıda alanındaki sektörde kullanılmalıdır.

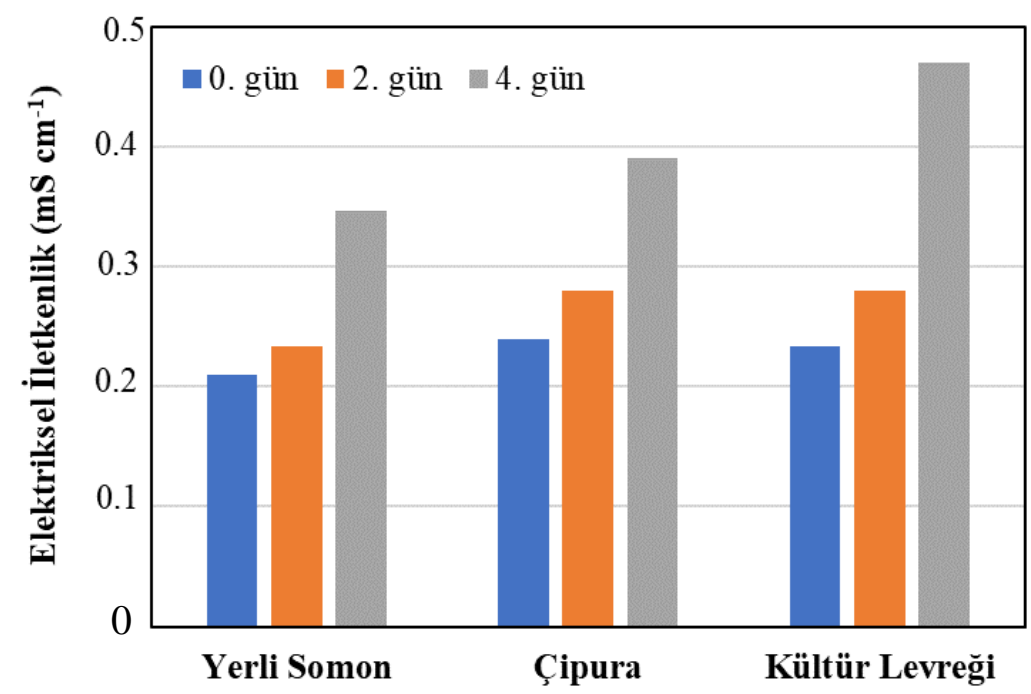

Şekil 1. YS, Ç ve L örneklerinde depolama günlerine bağlı olarak değişen elektriksel iletkenlik değerleri 


\section{Yüzey Gerilimi}

Yüzey gerilimi değerleri ve değişimleri Şekil 2'de verilmiştir. YS, Ç ve L eti örneklerinin başlangıç yüzey gerilimi değerleri sırasıyla 38.22, 42.56, $37.57 \mathrm{mN} \mathrm{m}^{-1}$ olarak tespit edilmiştir. Medina ve ark. (2009) Norveç somonu yüzeyinde yaptıkları çalışmada, yüzey gerilimi değerini $60.64 \mathrm{mN} \mathrm{m}^{-1}$ olarak tanımlamıştır. Ayrıca bu çalışmada adhezyon olarak tanımlanan yapışkanlık özelliğinin de yüzey gerilimini belirlemede önemli bir fonksiyonu olduğunu belirtmişlerdir. Bu noktada ise Michalski ve ark. (1997), adhezyon değeri üzerinde balıketinin sahip olduğu protein gibi yapıların, yă̆ karbon hidroksitlerinin de etin yapışma mekanizması üzerinde önemli bir rol oynadığı belirtmiştir. Bilindiği üzere depolama süresinin artması ile oksidasyona bağlı olarak balık yağlarının kalitesini önemli düzeyde etkilemektedir. Proteolitik aktivite ise balıketinde bulunan proteinlerin degrade olması, aynı zamanda balığın bozulmasına da sebep olabilmektedir (Sriket, 2014; Zhang ve ark., 2019). Zaten, yapışkanlık değeri depolamaya bağlı olarak değişim gösterebildiği hatta Dunnewind ve ark. (2004)'e göre; yapışkanlık değeri ile gıdalardaki duyusal karakterler arasında bir ilişki olabildiği belirtilmiştir. Yukarıda belirtilen verilen birbiri ile ilişkili bilimsel ifadeler ortaya koymaktadır ki yüzey gerilimi önemli bir kalite parametresi olarak değerlendirilebilir. Çalışmamız sonuçları da bu zincir kalite parametrelerini doğrular niteliktedir. Duyusal kalitedeki değişimlerle beraber, yüzey gerilimi değerleri YS örneklerinde $38.22 \mathrm{mN} \mathrm{m}^{-1}$, den $21.71 \mathrm{mN} \mathrm{m}^{-1}$,e kadar düşmüştür. Öte yandan Ç örneklerine ait değerler ise; $42.56 \mathrm{mN} \mathrm{m}^{-1}$ ' den depolamanın son gününde $25.23 \mathrm{mN} \mathrm{m}^{-1}$ ' e, L örneklerinin yüzey gerilimi değerleri ise $37.57 \mathrm{mN} \mathrm{m}^{-1}$, den $17.56 \mathrm{mN} \mathrm{m}^{-1}$ 'e kadar azaldı̆̆ 1 tespit edilmiştir. Sonuç olarak analiz edilen balık örneklerinde, yüzey gerilim analizi önemli ve hızlı bir kalite parametresi olarak değerlendirilebileceği ortaya konulmuştur.

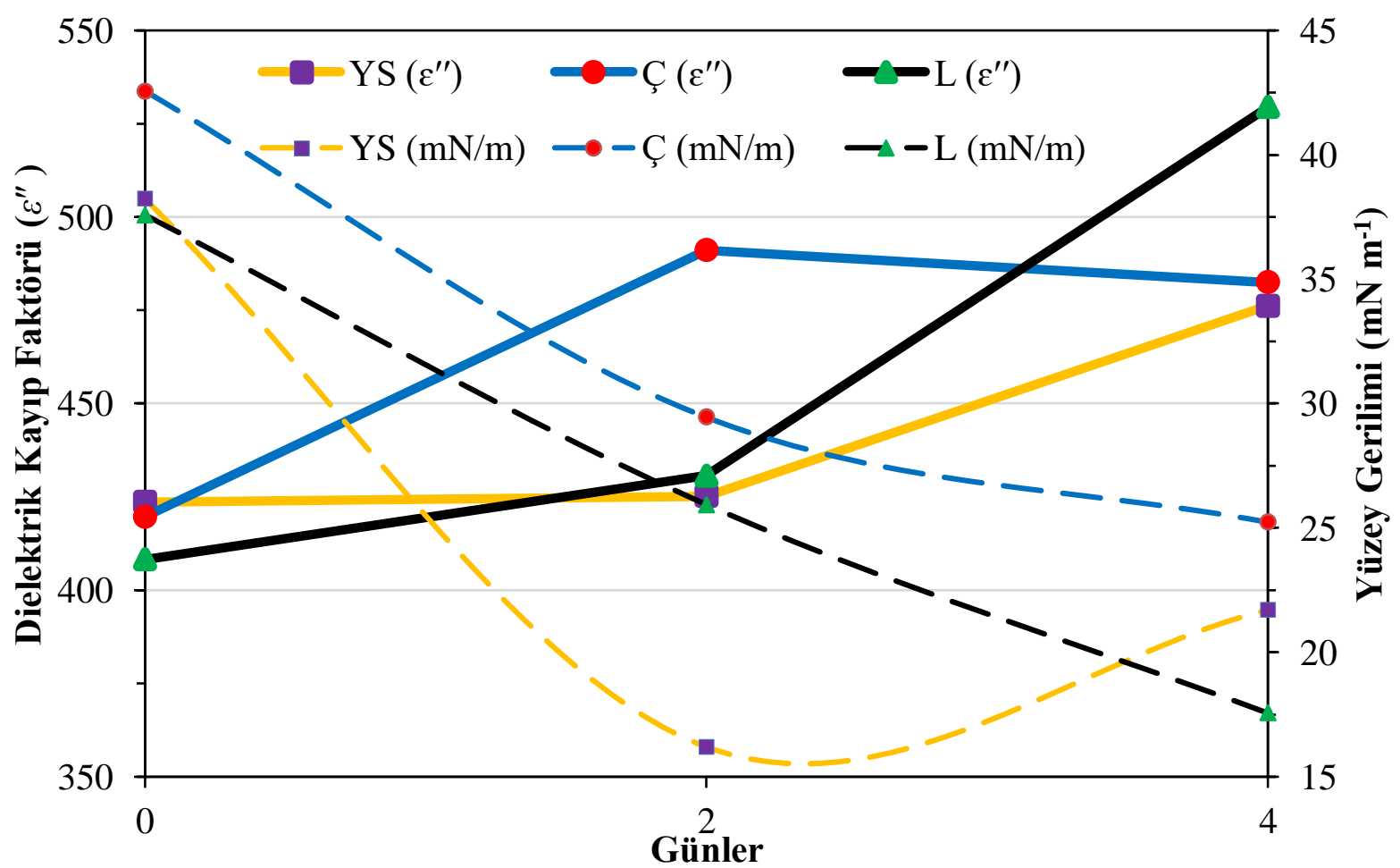

Şekil 2. YS, Ç ve L örneklerinde depolama günlerine bağlı olarak $30 \mathrm{MHz}$ frekansındaki dielektrik kayıp faktörü ve yüzey gerilimi değerleri. 


\section{Dielektrik Kayıp Faktörü}

Dielektrik kayıp faktörü uygulanan bir elektrik alanına veya çeşitli polarizasyon mekanizmasına yanıt olarak enerji yayma yeteneğini açıklar. Böylece enerji emilimi etkilenmekte olup, genellikle 1s1 ortaya çıkar (Sosa-Morales ve ark. 2010). Gıdaların dielektrik özelliklerini ya da başka bir ifade ile düşük ya da yüksek dielektrik kayıp faktörüne sahip olmalarını etkileyen faktörlerin başında su içeriği gelmektedir (Tıraş ve ark., 2019). Çalışmada incelen üç farklı gıda ürünü de aslında bir su ürünü olup, su ürünlerinin de nem oranın çoğu gıdaya kıyasla daha yüksek olduğu bilinmektedir. YS, Ç ve L örneklerine ait dielektrik kayıp faktörü sonuçları Şekil 2'de verilmiştir. İncelen örneklerin başlangıç dielektrik kayıp faktörü değerleri 423.59 ile 408.21 aralığında bulunmuştur. Depolamanın artışına bağlı olarak, dielektrik kayıp faktörü YS örneklerinde 423.59'dan 476.27'e çıkarken bu değişim yüzde olarak \%12.4 olarak tanımlanmıştır. Dahası levrek örneklerinde ise bu artış hızı daha fazla (\%29.68) olduğu belirlenmiştir. Raf ömrü süresince örneklerde nem kayıpları yaşanabilmektedir. Bu durum dielektrik kayıp faktörü değerlerinin artması ile ilişkili olmuş olabilir. Su gıdadan kendiliğinden raf ömrü boyunca uzaklaşabildiği gibi, aynı zamanda ısıl işleme bağlı olarak da gıdadan uzaklaştırılabilmektedir. Bu durumu başka bir ifade Cao ve ark. (2019) çalışmasında görmek mümkündür. Farklı sıcaklık artışlarında $\left(20^{\circ} \mathrm{C}^{\prime}\right.$ den $90^{\circ} \mathrm{C}$ 'ye) balık surimi jellerinin dielektrik kayıp faktörü değeri 29.61 'den 42.50 'ye artmıştır. $\mathrm{Bu}$ çalışmada yapılan mikrodalga işlemi (1sıl işlem) suyun uzaklaşmasına ve dielektrik kayıp faktörü değerinin yaklaşık \%43.53 gibi büyük bir oranda artmasına neden olmuştur. Çalışmamızda da bozulmaya bağlı olarak dielektrik kayıp faktörü değerinin arttığı tespit edilmiştir. Hatta taze ürün ile bayat ürün arasındaki yüzdesel farklar \%29.68'lere kadar ulaşmıştır. Bu bağlamda, sunulan çalışmada bozulmanın hızlı olarak tespit edilmesinde, bu yöntem için en aktif sonucu L örnekleri vermiştir.

\section{Partikül Boyutu ve Polidispersite İndeksi}

Çalışmamızda farklı örneklere ait PB değişimleri ve PDI değişimleri de incelenmiştir. PB değerleri arasında anlamlı bir ilişki tespit edilmemiştir. Buna benzer olarak örneklerin PDI değerleri maksimum 1 ila minimum 0.5 arasında değişim göstermesine rağmen bozulma ile ilişkili bir değer değişimi tespit edilememiştir.

Çizelge 2. Depolama süresince değişen PB ve PDI değerleri

\begin{tabular}{lccc}
\hline \multicolumn{1}{c}{ Analiz Günleri } & 0. Gün & 2. Gün & 4. Gün \\
\hline Yerli Somon & PB (dnm)/PDI & PB $($ dnm $) / P D I$ & PB $($ dnm $) /$ PDI \\
Çipura & $4814^{\mathrm{c}} / 1^{\mathrm{a}}$ & $7951^{\mathrm{b}} / 1^{\mathrm{a}}$ & $11136^{\mathrm{a}} / 0.5^{\mathrm{b}}$ \\
Levrek & $7091^{\mathrm{a}} / 0.8^{\mathrm{b}}$ & $7173^{\mathrm{a}} / 1^{\mathrm{a}}$ & $2696^{\mathrm{b}} / 1^{\mathrm{a}}$ \\
\hline
\end{tabular}

${ }^{a, b, c}$ harfleri analiz günleri arasındaki istatistiksel farklılığ ifade etmektedir $(\mathrm{p}<0.05)$

\section{Duyusal Analiz}

Duyusal analiz yorum ve sonuçları Çizelge 3 'te verilmiştir. Tüm ürünler $10 \pm 2{ }^{\circ} \mathrm{C}$ aralığında muhafaza edilmiştir. Ürünlerin (YS, Ç ve L) başlangıç kalitesi 10 puan üzerinden 9 puan olarak tanımlanmıştır ( $>0.05$ ). Hammaddenin başlangıç kalitesi, bozulma hızında anahtar rol oynar (Huss 1994). Depolama sıcaklığının $4{ }^{\circ} \mathrm{C}$ 'den yüksek tutulmasına bağlı olarak, YS örnekleri depolamanın 2. gününde 4.5 ortalama genel kabul edilebilirlik değerine düşerken $(p<0.05)$, Ç ve L örnekleri ise $<4$ puan almıştır ( $\mathrm{p}>0.05)$. Bu sonuçlara göre, YS örnekleri duyusal kabul edilirlik değerinin altında, diğer iki örnek ise 2. gün itibari ile tüketilemez olarak kabul edilmiştir. 
Çizelge 3. Depolama süresince değişen duyusal puanlar ve gözlemler

\begin{tabular}{lccc}
\hline & 0. Gün & 2. Gün & 4. Gün \\
\hline Yerli Somon & $9^{\mathrm{a}}$ & $4.5^{\mathrm{b}}$ & $1.5^{\mathrm{c}}$ \\
Duyusal Gözlemler & Canlı renk & Su/yağ salma, orta koku, yumuşama, & Sineklenme \\
Cipura & $9^{\mathrm{a}}$ & vicıklaşma, renk solması & $0.75^{\mathrm{b}}$
\end{tabular}

Çipura $9^{\mathrm{a}}$

Duyusal Gözlemler Sert yap1, canlı renk

Levrek

$9^{\mathrm{a}}$

Çok ağır koku, su salma, yapıda bozulma, gözler tamamen mat, belirgin renk değişimi

$1^{\mathrm{b}}$

Çok daha ağır koku, su salma, yapıda bozulma, gözler tamamen mat, yapay görüntü, belirgin renk değişimi
Gözlerde

k1zarma

$0.25^{\mathrm{b}}$

Gözlerde

k1zarma

$\overline{\mathrm{a}, \mathrm{b}, \mathrm{c}}$ gruplar arasındaki istatistiksel farklılığı tanımlar $(\mathrm{p}<0.05)$

Balık ve balıktan elde edilen ürünlerde duyusal kalite ya da farklılıkları belirleyen en önemli kriterlerden bazıları balık türü ve etteki doğal flora olarak tanımlanmaktadır (Berik ve Kahraman, 2010). Sunulan çalışmanın duyusal sonuçları çalışmanın tam olarak amacı ile de uyuşmaktadır. Hızlı bozulan üründe meydana gelen kalite değişimleri yine hızlı yöntemlerle (dielektrik özellikleri, elektriksel iletkenlik vs.) teşhis edilmiştir. Ayrıca duyusal analiz günlerine bağlı olarak görülen görsel değişimler Şekil 3, 4, ve 5'te gösterilmiştir.

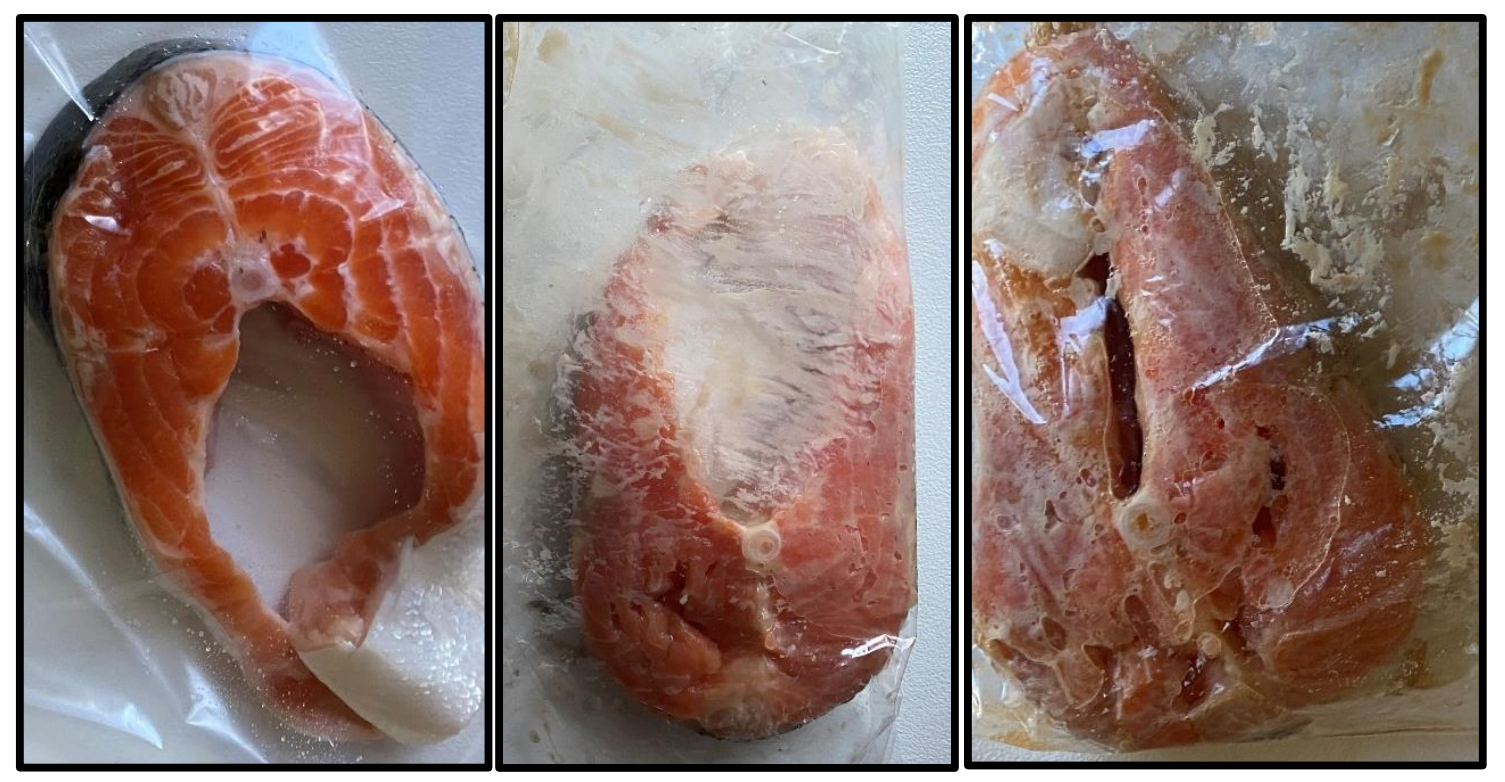

Şekil 3. 0. gün, 2. gün ve 4. gündeki yerli somon örneklerinin görsel fotoğrafları (soldan sağa) 


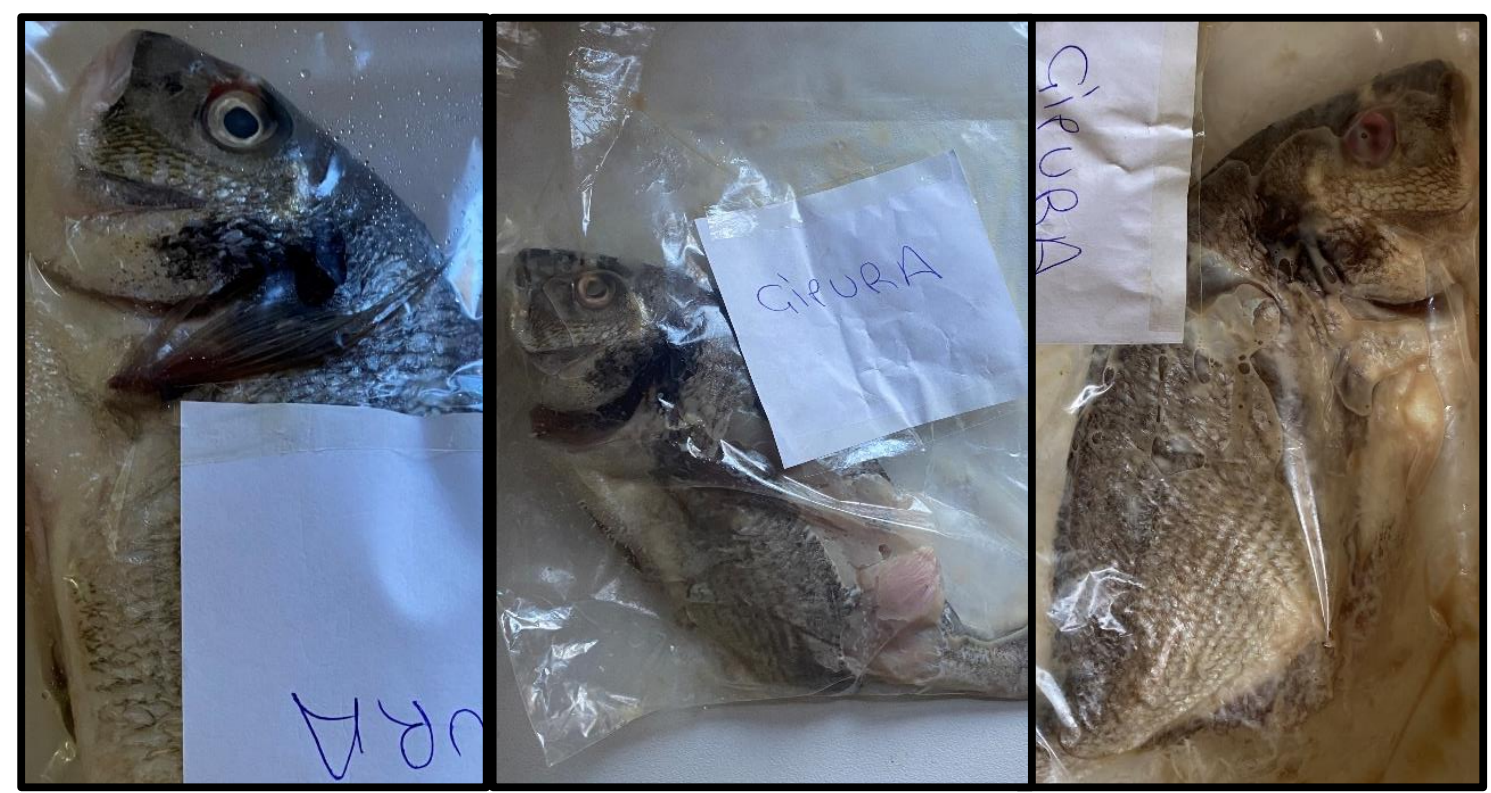

Şekil 4. 0. gün, 2. gün ve 4. gündeki çipura örneklerinin görsel fotoğrafları (soldan sağa)

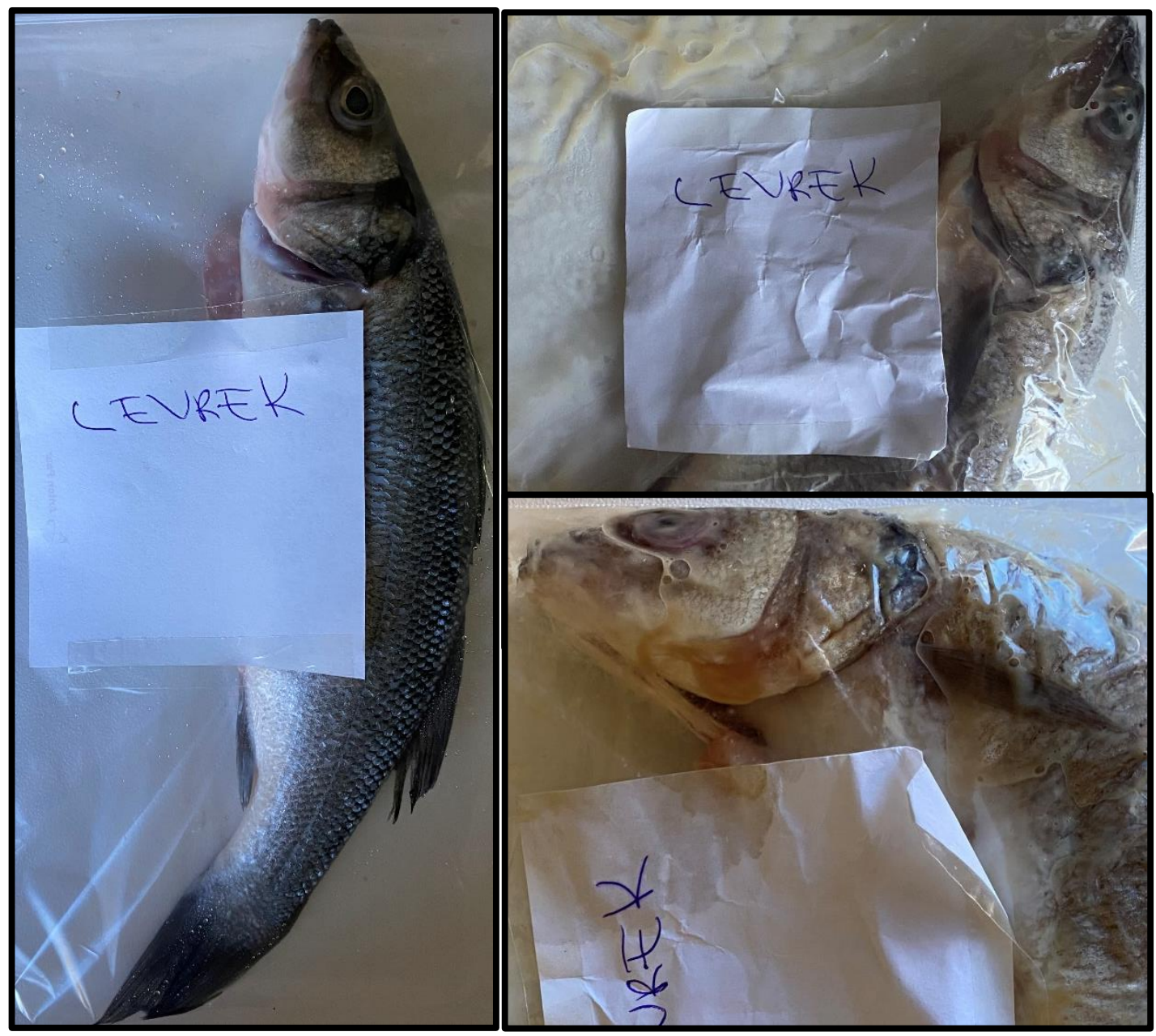

Şekil 5. 0. Gün (sol), 2. gün (sağ üst) ve 4. gündeki (sağ alt) levrek örneklerinin görsel fotoğrafları 


\section{SONUÇ}

L, Ç ve YS örneklerine ait et örneklerindeki $\mathrm{pH}$, elektriksel iletkenlik ve dielektrik kayıp faktörü değerleri depolama süresine bağlı olarak artmıştır. Ancak, örneklere ait yüzey gerilim değerleri ise düşüş göstermiştir. Duyusal kayıplarda çalışmada gözlenmiş olup, yukarıda belirtilen analizlerle uyumlu şekilde değişimler tespit edilmiştir. Bu çalışma ile balık gibi besin içeriği bakımından değerli ama hızlı kalite kayıpları yaşayabilen gıda materyallerinin bu açıdan incelenmesi son derece önemli bulunmuştur. Bu bakımdan ileriki çalışmalarda belirtilen analizlere araştırmacıların makale ya da araştırmalarda daha çok yer vermesi, gıda işleme ve kalite kontrol laboratuvarlarında bu parametrelere daha çok yer vermeleri tavsiye edilmektedir.

\section{TEŞEKKÜR}

Bu çalışma, İstanbul Teknik Üniversitesi Bilimsel Araştırma Projeleri Koordinasyon Birimince desteklenmiştir. Proje Numarası: 42144.

\section{Çıkar Çatışması}

Makale yazarları aralarında herhangi bir çıkar çatışması olmadığını beyan ederler

\section{Yazar Katkısı}

Yazarlar makaleye eşit oranda katkı sağlamış olduklarını beyan eder.

\section{KAYNAKLAR}

Abbas KA, Mohamed A, Jamilah B, Ebrahimian M, 2008. A review on correlations between fish freshness and $\mathrm{pH}$ during cold storage. American Journal of Biochemistry and Biotechnology, 4 (4): 416-421.

Aydar AY, Bağdatlığlu N, 2014. Yemeklik Yağların Yüzey Gerilimi ve Temas Açılarının Belirlenmesinde Uygulanan Yöntemler. Akademik Gıda, 12 (1): 108-114.

Bendini A, Cerretani L, Carrasco-Pancorbo A, Gómez-Caravaca AM, Segura-Carretero A, FernándezGutiérrez A, Lercker G, 2007. Phenolic molecules in virgin olive oils: A survey of their sensory properties, health effects, antioxidant activity and analytical methods. An overview of the last decade. Molecules, 12 (8): 1679-1719.

Berik N, Kahraman D, 2010. Kefal Balığı Sucuklarında Duyusal ve Besin Kompozisyonun Belirlenmesi. Kafkas Universitesi Veteriner Fakültesi Dergisi, 16 ((Suppl-A)): S59-S63.

Cano-Sarmiento C, Téllez-Medina DI, Viveros-Contreras R, Cornejo-Mazón M, Figueroa-Hernández CY, García-Armenta E, Alamilla-Beltrán L, García HS, Gutiérrez-López GF, 2018. Zeta Potential of Food Matrices. Food Engineering Reviews, 10 (3): 113-138.

Cao H, Fan D, Jiao X, Huang J, Zhao J, Yan B, Zhou W, Zhang W, Ye W, Zhang H, 2019. Importance of thickness in electromagnetic properties and gel characteristics of surimi during microwave heating. Journal of Food Engineering, 248: 80-88.

Çetinkaya T, Ceylan Z, 2020. Balıketi Kalitesinin Tanımlanmasında Kullanılabilecek Alternatif Yaklaşımlar. Ziraat, Orman ve Su Ürünleri Alanında Akademik Çalışmalar-II. Gece Kitaplığı Yayınevi, s. 73-91, Ankara-Türkiye.

Ceylan Z, 2019. A new cost-effective process for limitation of microbial growth in fish fleshes: Wrapping by aluminum foil coated with electrospun nanofibers. Journal of Food Safety, 39 (5) :18. 
Ceylan Z, Meral R, 2018. Determination of Textural and Color Parameters of Fish Fillets Stored at Refrigerated Conditions. International Journal of Scientific and Technological Research, 4 (10): 320-326.

Ceylan Z, Özoğul Y, 2019. Irradiation Technology. Innovative Technologies in Seafood Processing. CRC Press, s.115-129, Boca Raton, Florida-USA.

Ceylan Z, Sengor GFU, Yilmaz MT, 2017. A Novel Approach to Limit Chemical Deterioration of Gilthead Sea Bream (Sparus aurata) Fillets: Coating with Electrospun Nanofibers as Characterized by Molecular, Thermal, and Microstructural Properties. Journal of Food Science, 82 (5): 11631170.

Ceylan Z, Unal Sengor GF, Basahel A, Yilmaz MT, 2018. Determination of quality parameters of gilthead sea bream ( Sparus aurata ) fillets coated with electrospun nanofibers. Journal of Food Safety, 38 (6): 1-7.

Chotimarkorn C, 2014. Quality changes of anchovy (Stolephorus heterolobus) under refrigerated storage of different practical industrial methods in Thailand. Journal of Food Science and Technology, 51 (2): 285-293.

Díaz P, Garrido MD, Bañón S, 2011. Spoilage of sous vide cooked salmon (Salmo salar) stored under refrigeration. Food Science and Technology International, 17 (1): 31-37.

Dunnewind B, Janssen AM, van Vliet T, Weenen H, 2004. Relative importance of cohesion and adhesion for sensory stickiness of semisolid foods. Journal of Texture Studies, 35 (6): 603-620.

Fan W, Sun J, Chen Y, Qiu J, Zhang Y, Chi Y, 2009. Effects of chitosan coating on quality and shelf life of silver carp during frozen storage. Food Chemistry, 115 (1): 66-70.

Gerdes DL, Santos Valdez C, 1991. Modified atmosphere packaging of commercial Pacific red snapper (Sebastes entomelas, Sebastes flavidus or Sebastes goodei). Lebensmittel - Wissenschaft + Technologie, 24 (3): 256-258.

Güzel N, Bahçeci KS, 2020. Çorum Yöresi Ballarının Bazı Kimyasal Kalite Parametrelerinin Değerlendirilmesi. GIDA / The Journal of FOOD, 45 (2): 230-241.

Huss HH, 1994. Assurance of seafood quality. FAO. Fisheries Technical Paper, 334: 46-53.

ICMSF (International Commission on Microbiological Specifications for Foods), 1986. Microorganisms in foods 2. Sampling for microbiological analysis: principles and specific applications. University of Toronto Press Toronto-Canada.

Jha SN, Narsaiah K, Basediya AL, Sharma R, Jaiswal P, Kumar R, Bhardwaj R, 2011. Measurement techniques and application of electrical properties for nondestructive quality evaluation of foodsa review. Journal of Food Science and Technology, 48 (4): 387-411.

Kaya O, İçier F, 2019. İndüksiyon ve Ohmik Isıtma İşlemlerinin Gıdalara Uygulanabilirliğinin Karşılaştırılması. Akademik Gıda, 17 (1): 111-120.

Kayim M, Can E, 2010. The $\mathrm{pH}$ and total fat values of fish meat in different iced storage period. Asian Journal of Animal and Veterinary Advances, 5 (5): 346-348.

Komarov V, Wang S, Tang J, 2005. Permittivity and Measurements. Encyclopedia of RF and Microwave Engineering. John Wiley \& Sons, Inc s. 3693-3711, Hoboken-NJ-USA.

Medina I, Gallardo JM, Aubourg SP, 2009. Quality preservation in chilled and frozen fish products by employment of slurry ice and natural antioxidants. International Journal of Food Science and Technology, 44 (8): 1467-1479.

Michalski MC, Desobry S, Hardy J, 1997. Food materials adhesion: A review. Critical Reviews in Food Science and Nutrition, 37 (7): 591-619. 
Nair K. 2002, Handling of Fish Onboard Fishing Vessels. Central Institute of Fisheries Technology, Matsyapuri-Cochin-India.

Ozogul Y, Yuvka İ, Ucar Y, Durmus M, Kösker AR, Öz M, Ozogul F, 2017. Evaluation of effects of nanoemulsion based on herb essential oils (rosemary, laurel, thyme and sage) on sensory, chemical and microbiological quality of rainbow trout (Oncorhynchus mykiss) fillets during ice storage. LWT - Food Science and Technology, 75: 677-684.

Özogul Y, Durmus M, Ucar Y, Özogul F, Regenstein JM, 2016. Comparative study of nanoemulsions based on commercial oils (sunflower, canola, corn, olive, soybean, and hazelnut oils): Effect on microbial, sensory, and chemical qualities of refrigerated farmed sea bass. Innovative Food Science and Emerging Technologies, 33: 422-430.

Pliquett U, Altmann M, Pliquett F, Schöberlein L, 2003. Py - A parameter for meat quality. Meat Science, 65 (4): 1429-1437.

Sosa-Morales ME, Valerio-Junco L, López-Malo A, García HS. 2010. Dielectric properties of foods: Reported data in the 21 st century and their potential applications. LWT - Food Science and Technology, 43 (8): 1169-1179.

Souza BWS, Cerqueira MA, Ruiz HA, Martins JT, Casariego A, Teixeira JA, Vicente AA, 2010. Effect of Chitosan-based coatings on the shelf life of Salmon (Salmo salar). Journal of Agricultural and Food Chemistry, 58 (21): 11456-11462.

Sriket C, 2014. Proteases in fish and shellfish: Role on muscle softening and prevention. International Food Research Journal, 21 (2): 433-445.

Tıraş B, Dede S, Altay F, 2019. Dielectric Properties of Foods. Turkish Journal of Agriculture - Food Science and Technology, 7 (11): 1805-1816.

Tyson WR, Miller WA. 1977, Surface free energies of solid metals: Estimation from liquid surface tension measurements. Surface Science, 62 (1): 267-276.

Zhang H. 2007. Electrical Properties of Foods. Food Engineering. Eolss Publisher Co. Ltd, s. 110-119, Oxford-England.

Zhang X, Huang W, Xie J, 2019. Effect of different packaging methods on protein oxidation and degradation of grouper (Epinephelus coioides) during refrigerated storage. Foods, 8 (8): 325. 